\title{
Language Learning Goals
}

\author{
Objetivos de Aprendizaje de Lenguas \\ Laura López-González ${ }^{a}$
}

\begin{abstract}
:
The most important actions we take in our lives are easier when we have set goals, because they are extraordinary tools to know where we are going, why we are going and how we are going. The creation of a lesson plan should begin with a clear learning goal that prevents us from losing the path and provides teachers and students with certainty. Learning goals make our lives as teachers both easier and more difficult. Easier because they help us determine to what extent our students have really developed certain competences, they help us answer objectively the question have they learned? More difficult, because it is a challenge to set them.
\end{abstract}

Keywords:

Learning goal, instructional objective, planning, form, function, Bloom's taxonomy

\section{Resumen:}

Las acciones más importantes que enfrentamos en nuestras vidas son más fáciles cuando establecemos metas ya que son herramientas extraordinarias para conocer hacia dónde vamos, las razones por las cuales vamos hacia ya así como la manera como lo conseguiremos. La creación de un plan de clase debe comenzar con el establecimiento de un objetivo claro de aprendizaje que nos prevenga de perdernos en el camino, asimismo, provee de certeza a docentes y estudiantes. Los objetivos de aprendizaje hacen nuestras vidas como docentes tanto más fáciles como más complicadas. Más fáciles pues nos ayudan a determinar hasta qué punto nuestros estudiantes han realmente desarrollado las competencias en cuestión, también nos ayudan a, objetivamente, responder la pregunta ¿han aprendido? Más complicada, ya que, en sí, es un reto importante establecerlas.

\section{Palabras Clave:}

Objetivo de aprendizaje, objetivo instruccional, planeación, forma, función, taxonomía de Bloom

\section{INTRODUCTION}

Teaching English is a process that starts with good planning. Planning is the establishment of pedagogically and didactically connected activities that create a unique sequence facilitated within a collaborative, learning community. In this community, teachers facilitate learning through activities, tasks, materials, resources among many other elements, whereas students receive this input in an active, never passive way; that is to say, learners must be the ones doing most, if not, all the work in the language classroom. Students are there to learn English and teachers, to help them.

Planning a language lesson is not an easy task. Basically, an effective lesson plan must have:

1. The level of the course according to the Common European Framework (CEFR)

2. A description of the group profile: Number of students, their age as well as part of their characteristics as learners (their weaknesses and strengths in terms of language use and skills).

3. The topic of the class: Preferably a topic that could be potentially interesting. Mexican traditions could be a more interesting topic than Simple past.

4. Activities and tasks: The specific actions that will be taken by students to enhance and stimulate learning.

5. Materials: All the electronic or tangible resources that will aid learning.

6. Time: The minutes or hours that should be devoted to doing the activities and tasks.

The seventh basic element is a learning goal. A learning goal is the corner stone of a lesson plan, its basis, the part from which all the other elements derive. An effective learning goal sets clearly what students should be able to do by the end of the lesson, the conditions under which this will be demonstrated and the evidence per se that will be shown. Even, it can include a standard, this is, what kind of mistakes or how many mistakes 
are allowed learners to make without interfering in the achievement of the goal.

\section{THE INSTRUCTIONAL OBJECTIVES OF ROBERT MAGER}

Definitely, the topic of leaning goals cannot be discussed without mentioning the name Robert Mager. In 1962, the American psychologist graduated from the Universities of Ohio and Iowa, Robert Frank Mager wrote the book Preparing Instructional Objectives in order to describe the importance of determining measurable, observable, realistic learning goals when delivering a training course.

The also called behavioral learning objectives, performancebased learning objectives, three-part learning objectives or instructional objectives; learning goals have three characteristics that can be easily identified as elements that teachers must describe when writing a learning goal.

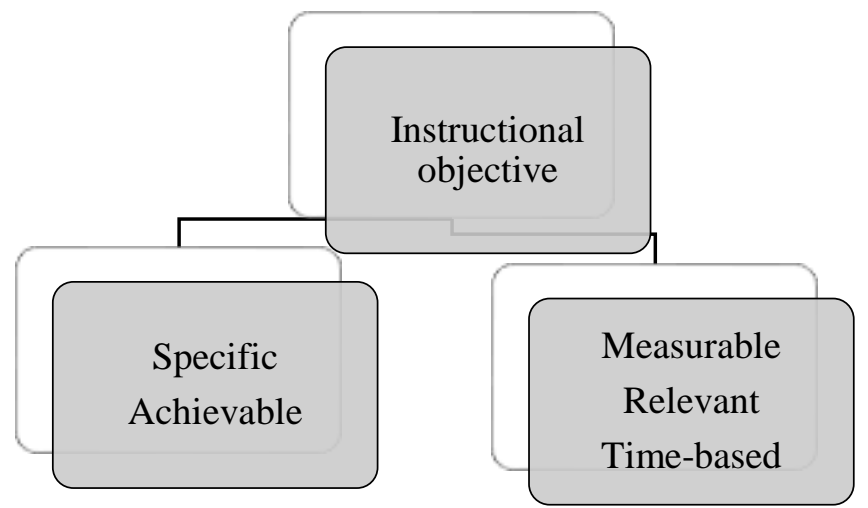

Figure 1. Characteristics of an instructional objective (Mager, 1962)

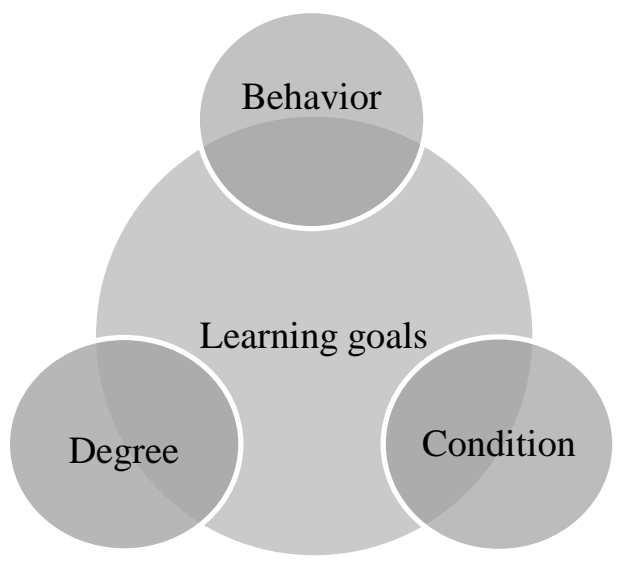

Figure 2. Elements of a learning goal (Mager, 1962)

Among the advantages of instructional objectives are:

- They are the basis for design. Based on instructional objectives, teachers can design activities, tasks and the materials that accompany them.

- The learning goals aid students and guide facilitators in the teaching and learning process.
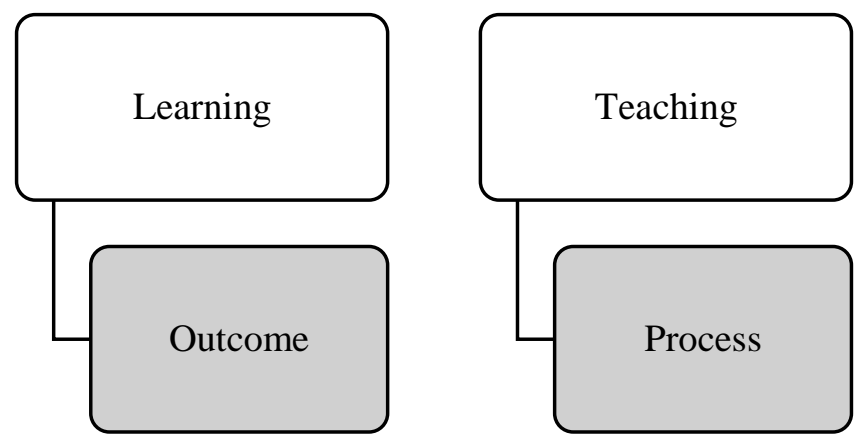

Figure 3. The representation of learning and teaching (Mager, 1997)

The advanges The ABCD method of writing learning objectives is not necessarily the only way to write them, but it has proved to be one of the most effective. ABCD stands for Audience, Behavior, Condition and Degree.

The ABCD method answers the questions who, what, how and how much?

Audience refers to those people who will be demonstrating what they learned after a period of instruction. They can be named as learners, students, participants, attendees, etc.

Behavior is the precise, tangible evidence that will be shown by learners. An example of this is a piece of writing, the narration of a story, the presentation of a topic or the participation in a debate.

Condition refers to the circumstances under which the behavior (evidence) will be done. For instance, the vocabulary or the grammatical structures students should use preferably.

Degree is a standard. The degree has to do with accuracy, the number of mistakes or the kind of mistakes that learners are allowed to make without being this a justification to say that they have not learned; therefore, that the learning goal has not been accomplished.

By the end of the lesson, students should be able to write an essay on the environmental crisis making use of the connectors however, therefore and despite as accurately as possible.

Audience: Students

Behavior: Writing an essay

Figure 4. Example of a learning goal written using the ABCD method
Condition: Use of connectors

Degree: As accurately as possible 
When the behavior is described, observable verbs must be included. Write, tell, narrate, describe, categorize, define, compare are all valid, reliable options because teachers can see a product to be evaluated without a doubt. Considering this, learn could never be part of a learning goal because is subjective and not observable. How can we say that somebody has learned? The answer to this question may always come from mere appreciation and not from a real evidence.

A wise way to proceed in order to determine the verbs to be used is consulting the taxonomy of educational objectives created in 1956 by Benjamin Bloom, Max Englehart, Edward Furst, Walter Hill and David Krathwohl.

\section{BLOOM'S TAXONOMY OR THE EASIEST PATH TO GUARANTEEING CONVENIENT VERBS}

The taxonomy created by Bloom is the mostly used way of organizing instructional objectives. When considering what Benjamin Bloom worked with his colleagues we are not looking at simple, mere verbs; we are looking into the world of cognitivism. For example, when a teacher sets a goal using the verb analyze, or any other synonym, she is assuming that students have already remembered and understood.

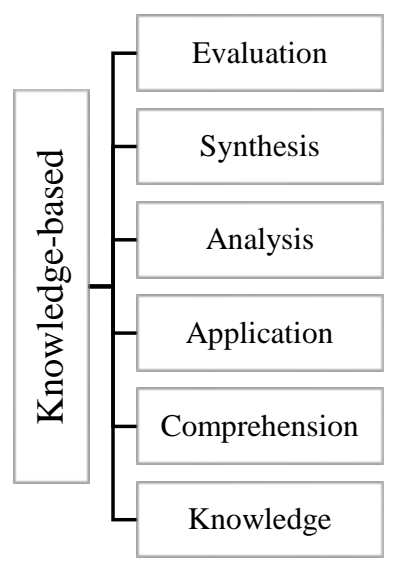

Figure 5. Knowledge-based levels of expertise in Bloom's taxonomy (1956)

For making learning goals more specific, teachers should determine precisely what they want to look at, in other words, the nature of evidence needed in order to show if there is progress in the learning process. The expected result of the learning process is competences developed. A competence is the combination of knowledge, skills and values that allow a person to be able to do a task successfully. Three different types of goals, then, derive from this, knowledge-based goals, skill-based goals and affective-based goals. To exemplify this, we could talk about the desired learning goals in a lesson on environment. If the lesson requires students to understand what ecosystems are and their elements, we would be talking about a knowledgebased goal. On the other hand, if they use the laboratory equipment to determine how contaminated a water sample is, then, a skill-based goal is present. Finally, if the teacher invites students to create a campaign to promote the protection of the environment with the school community and their families, an affective, values-based goal is being achieved.

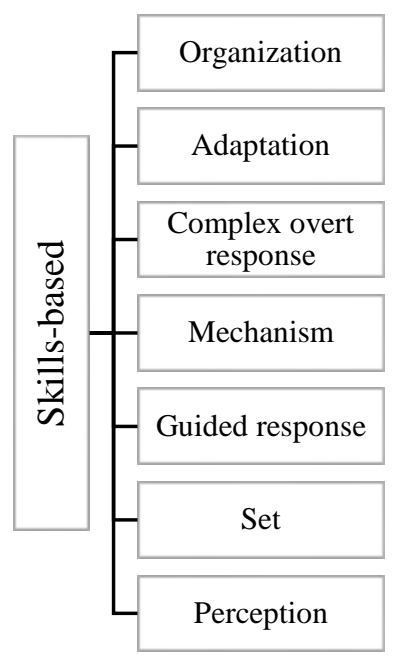

Figure 6. Skills-based levels of expertise in Bloom's taxonomy (1956)

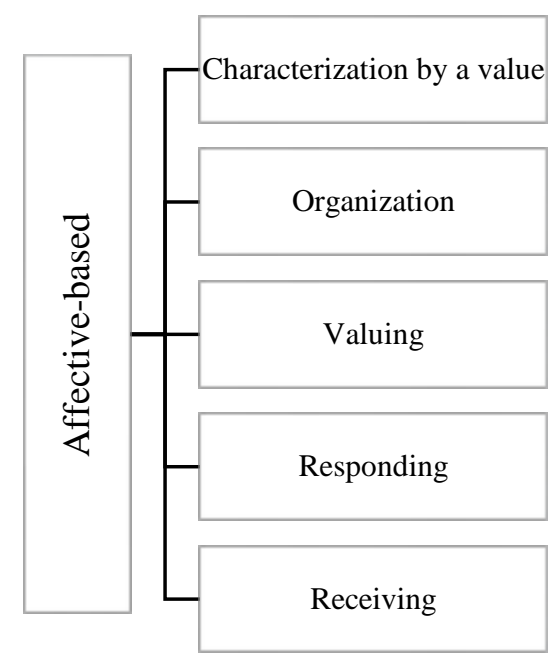

Figure 7. Affective-based levels of expertise in Bloom's taxonomy (1956)

A group of psychologists, theorists and researchers published the revised version of Bloom's taxonomy in 2001. The main extraordinary change was to refer to the cognitive stages in terms of verbs instead of using nouns. A big difference that makes this taxonomy a more dynamic one is having deleted the passiveness of the focus on goals, drawing now the attention to what the students are actually doing, step by step, the actions, the verbs. Another incredible thing is that one step more was added: Creation. This is evolution in education, students are no longer only required to analyze and evaluate but create. Creation then represents the highest level of learning. 


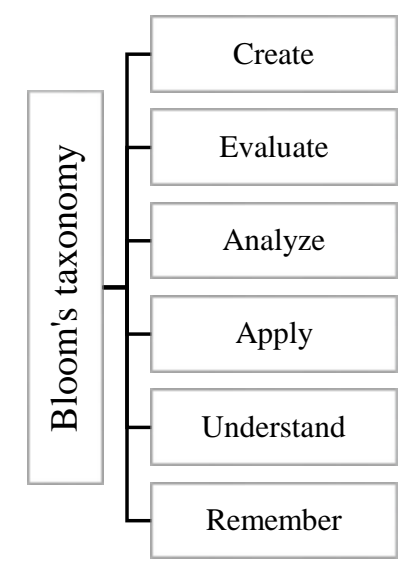

Figure 8. Levels of expertise in Bloom's taxonomy in 2001

\section{THE LINGUISTIC AND FUNCTIONAL VIEWS OF THE LANGUAGE}

In 1995, an expert who is a classic in the world of communicative language teaching, Littlewood, stated one of the most characteristic features of communicative language teaching is that it pays systematic attention to functional as well as structural aspects of language, combining these into a more fully communicative view.

On the one hand, the linguistic view of the language has to do with vocabulary, grammar, tenses and all those elements that are described purely by the science of linguistics. On the other hand, the functional view refers to what is actually done with the language: describe, define, compare, tell, criticize, suggest, and understand; just to mention a couple of examples.

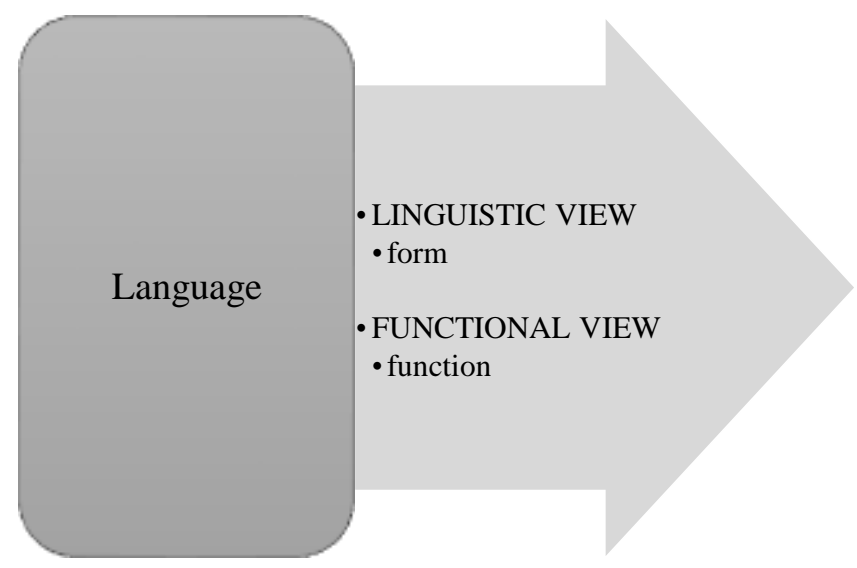

Figure 9. Views of language (Littlewood, 1995)

The importance of including these views when writing goals is obvious since communication in the language that is being learned is not possible if students only know how to structure ideas, for instance, in simple present (following the pattern: subject, verb, complement) without knowing how to communicate and exchange ideas and opinions in a lesson about laws of nature, which generally are explained and described using the simple present.

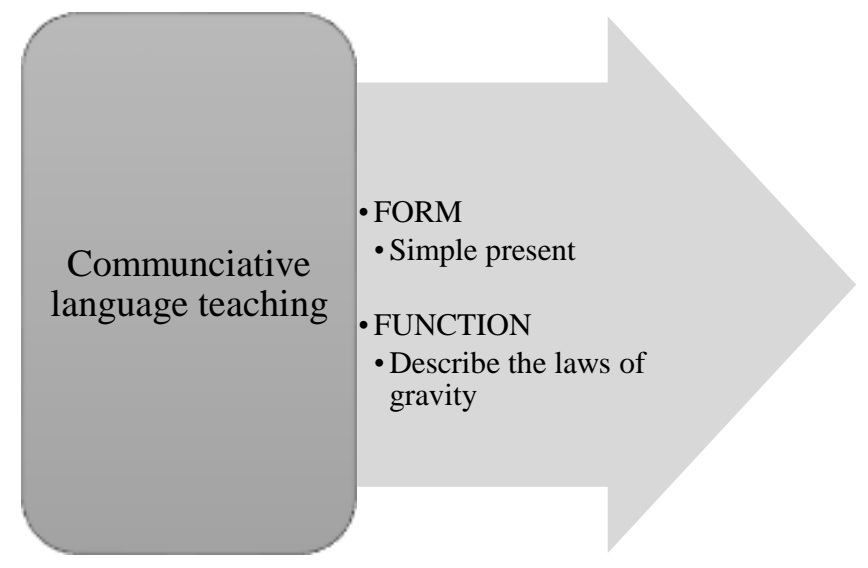

Figure 10. Example of form and function correspondence

Having said this and considering that Communicative Language Teaching is not communicative if systematic attention is not paid to both views, then, teachers should write goals close to what is shown in Figure 11.

By the end of the lesson, students should be able to describe the laws of gravity making use of the simple present as accurately as possible.

\section{Audience: Students}

Behavior: Describe the laws of gravity

Figure 11. Example of a learning goal written using the $A B C D$ method combining form and function of the language

Communicative Language Teaching is not only connected to oral production or to productive skills, on the contrary, this approach demands the mastery of all four skills; listening, writing, speaking and reading so that foreign language learners can use them to express what they think, feel or need in different contexts and talking about different topics.

The CEFR is a tool to be exploited for planning truly communicative language courses since it provides descriptors, concepts and definitions as well a list of can-do statements in order for us to be aware of what a speaker of a second language is capable of doing as he progresses in the learning process. This certainly impacts our daily planning and teaching. 


\section{CONCLUSIONS}

- Level of the course, group profile, topic, activities, tasks, materials, time and the learning goal are basic elements of a language lesson plan.

- The ABCD method of writing instructional objectives by Robert Mager is not the only method of writing them but one of the most recommendable.

- $\mathrm{ABCD}$ stands for Audience, Behavior, Condition and Degree.

- A learning goal must be SMART: Specific, Measurable, Achievable, Relevant and Time-based.

- Bloom's taxonomy is an extraordinary tool for determining wisely what will be set as the expected result of any given lesson.

- Both the linguistic and the functional views of the language must be part of the learning goals that are set for guaranteeing communicative-oriented lessons.

- The CEFR and its can-do statements and descriptors always aid the implementation of communicative language teaching and form and function-based learning goals.

\section{REFERENCES}

[1] Anderson, Lorin W., Krathwohl, David R., and Bloom, Benjamin S. A Taxonomy for Learning, Teaching, and Assessing: a Revision of Bloom's Taxonomy of Educational Objectives / Editors, Lorin W. Anderson, David Krathwohl ; Contributors, Peter W. Airasian ... [et al.]. Complete ed. New York: Longman. Print.

[2] Bloom, B. S., Englehart, M. D., Furst, E. J., Hill, W. H., \& Krathwohl, D. R. (1956). The Taxonomy of educational objectives, handbook I: The Cognitive domain. New York: David McKay Co., Inc. [3] Huitt, W. (2000). Bloom et al.'s taxonomy of the cognitive domain. Retrieved $\begin{array}{llll}\text { October 27, 2019, from } & \text { 27, }\end{array}$ http://chiron.valdosta.edu/whuitt/col/cogsys/bloom.html.

[3]Littlewood, W. (1996). La enseñanza comunicativa de idiomas. Introducción al enfoque comunicativo. Madrid: Cambridge University Press. (Original en inglés de 1981).

[4] Lohr, L (no date). Objectives, sequencing, strategies.. Retrieved October 27, 2019 from http://www.coe.unco.edu/LindaLohr/home/et502_cbt/Unit3/Unit3_me nu.html.

[5] Mager, R. F. (1984). Preparing instructional objectives (2nd edition). Lake Publishing Company: Belmont, California. Retrieved October 27, 2019 from www.gsu.edu/ mstmbs/CrsTools/Magerobj.html.

[6] Mager, R.F. (1997). Preparing instructional objectives: A critical tool in the development of effective instruction(3rd ed.). Atlanta, GA: Center for Effective Performance.

[7] O’Neill, G., Murphy, F. (2010). Assessment. Retrieved October 28, 2019 from http://www.ucd.ie/t4cms/ucdtla0034.pdf.

[8] Thamarana, S. (2015). A Critical Overview of Communicative Language Teaching. Retrieved October 28, 2019 from https://www.researchgate.net/publication/282877159_A_Critical_Over view_of_Communicative_Language_Teaching.

[9] UNC Charlotte. (2019). Bloom's Taxonomy of Educational Objectives. Retrieved October 28, 2019 from https://teaching.uncc.edu/services programs/teaching-guides/course-design/blooms-educationalobjectives. 